\title{
INFLUÊNCIA DA TORREFAÇÃO DE GRÃOS DE CAFÉ (Coffea canephora), SOBRE COMPOSTOS BIOATIVOS E CRESCIMENTO DE LINHAGEM TUMORAL DE PRÓSTATA
}

\section{Deborah de Almeida Bauer Guimarães 1 ; Nathállia Jordão de Araújo Silva²; Otniel}

Freitas-Silva ${ }^{3}$; Anderson Junger Teodoro ${ }^{1}$ bauer.deborah@ hotmail.com

${ }^{1}$ Programa de Pós-Graduação em Alimentos e Nutrição (PPGAN) - Universidade Federal do Estado do Rio de Janeiro (UNIRIO), Brasil. ${ }^{2}$ Escola de Nutrição - Universidade Federal do Estado do Rio de Janeiro (UNIRIO), Brasil. ${ }^{3}$ Empresa Brasileira de Pesquisa Agropecuária (EMBRAPA Alimentos), Brasil.

O café é uma das bebidas mais antigas, mais consumidas no mundo e uma importante fonte de ácidos clorogênicos na dieta. Durante a torrefação do café, esses compostos com função bioativa, podem ser transformados e degradados quando submetidos à temperatura elevada. Dessa forma, esse estudo teve como objetivo avaliar o efeito do processamento de torra nos grãos de café na atividade antioxidante e antiproliferativa de células cancerosas de próstata humana. Os grãos de café robusta foram selecionados, os grãos verdes $(\boldsymbol{S} \boldsymbol{V})$ foram moídos em moedor analítico, os grãos das torras: clara $(\boldsymbol{S C})$, média $(\boldsymbol{S M})$ e escura $(\boldsymbol{S E})$ foram torrados em torrador Gene Café®. Após os grãos torrados atingirem temperatura ambiente, foram moídos em moedor caseiro e em seguida em moedor analítico. As amostras foram peneiradas $(710 \mu \mathrm{m})$ e extraídas em água quente e Ultrassom. Para a obtenção do pó de extrato de café, o conteúdo da extração foi centrifugado, retirado o sobrenadante e seco em Spray Dryer. Foram realizadas análises de DPPH, ABTS, FRAP, compostos fenólicos totais, viabilidade celular e apoptose. A linhagem celular de tumor de próstata (DU-145) foi cultivada sob condições ideais e analisadas 24 horas após tratamento com extratos de café $(25-5000 \mu \mathrm{g} / \mathrm{mL})$. Os dados obtidos foram submetidos à análise de variância (ANOVA) e as médias comparadas através do teste de Tukey $(\mathrm{p}<0,05)$, utilizandose o programa GraphPad Prism 5. Os resultados obtidos mostraram que os extratos de café verde e torra clara, apresentaram o maior potencial antioxidante e conteúdo de compostos fenólicos totais quando comparados aos grupos de torras mais escuras. Nas análises antioxidantes as amostras $\boldsymbol{S V}$ e $\boldsymbol{S C}$ apresentaram 80 e $81 \%$ de redução do radical DPPH, respectivamente. $\boldsymbol{S C}$ apresentou 129,16 mmol de trolox/100g em ABTS e em FRAP 392,28 $\mu$ mol de $\mathrm{Fe}^{+2} / 100 \mathrm{~g}$, com mais elevado potencial. Na análise de MTT, as quantidades mínimas de amostra $(\mu \mathrm{g} / \mathrm{mL})$ para reduzir 50\% das células tumorais ( $\left.\mathrm{IC}_{50}\right)$ foram de 5,19 (SV), 6,33 (SC), 7,48 (SM) e 7,32 (SE). No ensaio de apoptose, os extratos promoveram a redução de células viáveis e aumento das células em apoptose, sendo os maiores aumentos relativos ao controle $(7,89$ e 10,96) obtidos com a concentração de $5000 \mu \mathrm{g} / \mathrm{mL}$ nos extratos de café verde e no café de torra clara, respectivamente. Sendo assim, os dados indicam que os compostos presentes nas amostras de café verde e de torra clara são os com maior potencial para reduzir a proliferação celular e interferir nos mecanismos de morte de células tumorais. Palavras-chave: Café; Processamento; Compostos Bioativos. 